\title{
Evidence of Coordinated and Adjustable Osmolytes Movements Following Hyposmotic Swelling in Rainbow Trout Red Blood Cells
}

\author{
Valérie Maxime \\ Institut de Recherche Dupuy De Lôme, UMR CNRS 6027, Université Bretagne Sud, C.E.R. Yves Coppens, \\ Campus de Tohannic, Vannes, France
}

\section{Key Words}

Regulatory volume decrease $\cdot$ Ionic and organic osmo-effectors $\bullet$ Coordinated process $\bullet$ Trout red blood cells $\cdot$ Intracellular $\mathrm{pH}$

\begin{abstract}
Background/Aims: The osmolytes involved in the volume regulation of hyposmoticallyswollen fish cells are well identified. However, if a coordination and adjustments of their fluxes are obvious, few studies have clearly illustrated these aspects. Methods: Trout red blood cells volume variations were estimated from water contents obtained by a gravimetric method. Intracellular $\mathrm{K}^{+}$and $\mathrm{Na}^{+}$contents, and $\mathrm{Cl}^{-}$content of haemolysed cells were determined by photometry and colorimetry, respectively. The taurine contribution to cell volume regulation was calculated from the net changes of water, $\mathrm{K}^{+}, \mathrm{Cl}^{-}$and $\mathrm{Na}^{+}$contents. The intracellular $\mathrm{pH}$ was calculated from the chloride distribution across the cells membranes according to the Donnan equilibrium. Results: Cells responses to a rapid change (from 296 to $176 \mathrm{mOsm} . \mathrm{kg}^{-1}$ ) of the saline osmolality were examined in three conditions designed to not impact (Hypo. I) or to reduce the $\mathrm{K}^{+}$(Hypo. II) and $\mathrm{Cl}^{-}$(Hypo. III) contributions to the volume regulation. Hypo. I condition caused an immediate increase in water content, followed by a $90 \mathrm{~min}$. full regulation, concomitant with gradual lowering of $\mathrm{K}^{+}$and $\mathrm{Cl}^{-}$contents and a surprising increase in $\mathrm{Na}^{+}$content. Hypo. II and III conditions showed a partial and complete volume regulation, respectively. This was made possible by an increase in the taurine involvement. These experiments allowed to confirm that $\mathrm{K}^{+}$and $\mathrm{Cl}^{-}$were released via $\mathrm{KCl}$ cotransport and by separate channels. The comparison of Hypo. I and III conditions led to the observation that the partially amiloride-sensitive $\mathrm{Na}^{+}$influx is proportional to the taurine efflux; the latter being sustained mainly by a $\mathrm{Na}^{+} /$taurine cotransport. The Hypo. II condition was suitable for the $\left(\mathrm{Na}^{+} / \mathrm{K}^{+}\right)$ATPase activity inhibition. This effect could explain the observed lack of $\mathrm{Na}^{+}$uptake, the consecutive depletion of intracellular taurine stock and the incomplete volume regulation.
\end{abstract}




\section{Cellular Physiology Cell Physiol Biochem 2021;55(S1):185-195 \\ \begin{tabular}{ll|l} 
and Biochemistry & $\begin{array}{l}\text { DOl: 10.33594/000000440 } \\
\text { Published online: 20 October } 2021\end{array}$ & $\begin{array}{l}\text { O 2021 The Author(s). Published by } \\
\text { Cell Physiol Biochem Press GmbH\&Co. KG }\end{array}$ \\
\cline { 2 - 3 }
\end{tabular} \\ Maxime: Coordination of Swelling-Activated Osmolytes Fluxes in Trout Red Blood Cells}

Finally, the results support the importance of taurine in $\mathrm{pH}$ control under Hypo. I (physiologic) condition. The alkalosis observed in Hypo. II and III conditions were the consequences of changes in the salines compositions, not of physiologic adjustments. Conclusion: The regulatory volume decrease process of trout RBCs is complex and adjustable through coordinated osmolytes movements. The obliged decrease in $\mathrm{K}^{+}$and/or $\mathrm{Cl}^{-}$contributions stimulates taurine and $\mathrm{Na}^{+}$pathways. This study highlights the importance of taurine as a compensatory variable in cell volume regulation and explains for the first time the significance of the $\mathrm{Na}^{+}$uptake during this process.

(C) 2021 The Author(s). Published by Cell Physiol Biochem Press GmbH\&Co. KG

\section{Introduction}

The maintenance of a constant volume is a prerequisite for normal cellular life. Fish are good models for cell volume regulation studies because their aqueous habitats expose them to a wide range of steady or fluctuating osmotic conditions. Many studies demonstrate that most fish cells are able to regulate their volume following their physical swelling [1]. Notably, given their circulation through epithelial tissues, red blood cells (RBCs) can be often exposed to osmotic challenges and subsequent volume disturbances. Thus, besides the relative ease with which they are isolated, RBCs are often used as models for volume regulation studies.

In vivo cell volume increase can be induced by exposure to hyposmotic extracellular fluid or by the increase in intracellular osmolytes concentrations as a consequence of a variety of metabolic or pathologic conditions. Fish RBCs, particularly, can also transiently swell in isosmotic conditions after the stimulation of the membrane $\mathrm{Na}^{+} / \mathrm{H}^{+}$exchanger by catecholamine hormones [2]. Whatever the cause, cell swelling induces an adaptive response named regulatory volume decrease (RVD) consisting of passive loss of inorganic and/or of some low molecular weight organic osmolytes, followed by osmotically-obliged water efflux leading to the restoration of cell volume. Because of its electrochemical gradient, $\mathrm{K}^{+}$is highly involved in this process. It is tightly coupled to its counterion $\mathrm{Cl}^{-}$thanks to electroneutral cotransporters. This coupling can also take place via parallel conductive pathways [3]. Among the different classes of cell organic compounds (amino acids, polyols and methylamines - [4]), the $\beta$-amino acid taurine plays a primary role in RVD, due to its relatively high concentration. It can also withstand large changes in its concentration without deleterious effects on cellular function [4]. It is present in teleost's RBCs at concentrations up to $55 \mathrm{mM}$ [5]. In this way, a significant hyposmotic swelling-activated taurine efflux has been demonstrated in RBCs of lamprey [6] and succeeding elasmobranchs and bone fish: skate [7], eel [8, 9], carp [10], rainbow trout [11, 12, 13], Atlantic salmon [14] and flounder $[8,15,16]$. Moreover, few works, all performed in rainbow trout $[11,12,17,18]$, describe an additional, so far unexplained, uptake of $\mathrm{Na}^{+}$in RBCs following an hyposmotic swelling. Such an effect is rather observed after a hypertonic cell shrinkage [3]. Its clear that the RVD process based on these osmolytes effluxes has to be controlled in a well-coordinated manner [19]. However, this aspect has received little attention. In addition, cell volume regulation is likely to induce a net transfer of acid-base equivalents across the membrane, but results are unclear. For example, a reversible and unexplained decrease in intracellular $\mathrm{pH}$ (pHi) of trout hepatocytes was induced by an hyposmotic stress [20]. On the contrary, a great stability of pHi during RVD process was reported in trout RBCs [11].

The first aim of this study was to estimate the respective importance of the osmotically active solutes involved in the RVD process of RBCs of rainbow trout (Oncorhynchus mykiss), with a specific attention to the apparently counter-productive $\mathrm{Na}^{+}$uptake. This intriguing result justify the choice of the fish species, since it has already been outlined, to our knowledge, solely in rainbow trout. Then, in an attempt to clarify the effect of RVD on pHi, the latter was calculated considering the link between proton and chloride transmembrane concentrations according to the Donnan equilibrium. 


\section{Cellular Physiology Cell Physiol Biochem 2021;55(S1):185-195 \\ \begin{tabular}{ll|l}
\cline { 2 - 2 } DOl: 10.33594/000000440 & (c) 2021 The Author(s). Published by
\end{tabular} \\ and Biochemistry Published online: 20 October 2021 Cell Physiol Biochem Press GmbH\&Co. KG \\ Maxime: Coordination of Swelling-Activated Osmolytes Fluxes in Trout Red Blood Cells}

\section{Materials and Methods}

\section{Fish, samplings and experimental design}

Fifty rainbow trout (Oncorhynchus mykiss L.; 800-1000 g) were obtained from a commercial hatchery (Lesneven, Brittany, France) and kept for at least one week at the laboratory, under natural photoperiod and temperature $\left(12-15^{\circ} \mathrm{C}\right)$ conditions, in a $400 \mathrm{l}$ tank supplied with flowing aerated freshwater. They were fed ad libitum with commercial dry pellets until the day before the experiment. After acclimatization, the fish were lightly-anaesthetised by immersion in tricaine methanesulfonate (Sigma - $50 \mathrm{mg}^{-1} \mathrm{l}^{-1}$ ). Whole blood samples (approximately $10 \mathrm{ml}$ ) were collected in heparinised syringes $(10 \mathrm{IU} / \mathrm{ml})$ by caudal puncture. Each sample allowed to perform two RVD challenges which conditions were randomly determined.

RBCs were exposed to isosmotic or one of three different hyposmotic conditions of the same level: The first one (Hypo. I) corresponds to a 50\% dilution of the main component $(\mathrm{NaCl})$ of the physiologic saline. The two others were made up in order to control the $\mathrm{K}^{+}$and $\mathrm{Cl}^{-}$transmembrane concentrations. In this way, Hypo. II saline had a high $\mathrm{K}^{+}$concentration suitable to abolish the transmembrane gradient of $\mathrm{K}^{+}$. In the Hypo. III saline, $\mathrm{NO}_{3}{ }^{-}$was used as a $\mathrm{Cl}^{-}$substitute to coerce $\mathrm{Cl}^{-}$to get out of the cell and to reduce its contribution to the RVD. Salines compositions are given in Table 1.

\section{Measurements}

Cells images analysis being unsuitable to the non-spherical shape of fish RBCs, their volume changes were indirectly estimated from their variations in water content according to a method allowing also the simultaneous measurement of the main ions contents [11]. The blood sample was centrifuged (2500 g for $5 \mathrm{~min}$ ) and the plasma and buffy coat removed by aspiration. The RBCs pellet was washed 3 times in isosmotic Cortland saline [21] $\left(\omega=295.9 \mathrm{mOsm} \cdot \mathrm{kg}^{-1}\right)$. After overnight normoxic incubation in a thermostatically controlled incubator $\left(15^{\circ} \mathrm{C}\right)$, the cells were supposed to be not in a catecholamine-stimulated condition [10]. The sample was then adjusted to $15 \%$ haematocrit with isosmotic saline and transferred to a tonometer supplied with humidified air at $15^{\circ} \mathrm{C}$. The cell suspension was hence allowed to equilibrate for at least 1 hour under slight agitation, to guarantee a steady state with respect to ions and water.

All the experiments were performed under normoxic conditions. Cells were exposed or not (control) to a moderate hyposmotic stress $\left(\omega \approx 176 \mathrm{m0sm} \cdot \mathrm{kg}^{-1}\right)$. This was achieved, after centrifugation $(2,500 \mathrm{~g}$ for $3 \mathrm{~min}$ ) of the suspension, by the substitution of the isosmotic saline for one of the iso- or hyposmotic salines. Ten minutes before and then at intervals $(5,10,20,30,60$ and $90 \mathrm{~min})$ after the hyposmotic stress, $2.5 \mathrm{ml}$ aliquots of the whole suspension were drawn from the tonometer. They were immediately poured into six $400-\mu \mathrm{l}$ nylon tubes and centrifuged at 30,000 $\mathrm{g}$ (Eppendorf centrifuge 5417C) for $5 \mathrm{~min}$. The resulting mass of packed cells was then separated from the supernatant by slicing the tube with a scalpel blade at the top of the red cell column. Cell water content was determined in duplicate by the gravimetric method comparing the cells masses before and after their total drying for 72 hours $\left(80^{\circ} \mathrm{C}\right)$. It was expressed as gram water per gram dry cell solids. In duplicate samples of haemolysed cells (perchloric acid 70\%), intracellular $\mathrm{K}^{+}$and $\mathrm{Na}^{+}$

Table 1. Composition of the experimental salines. Osmolalities are expressed as mean \pm S.E.M

\begin{tabular}{|c|c|c|c|c|}
\hline Concentrations (mM) & Isosmotic & $\begin{array}{c}\text { Hyposmotic } \\
\text { (Hypo. I) }\end{array}$ & $\begin{array}{c}\text { Hyposmotic high-K+ } \\
\text { (Hypo. II) }\end{array}$ & $\begin{array}{c}\text { Hyposmotic Cl--free } \\
\text { (Hypo. III) }\end{array}$ \\
\hline $\mathrm{NaCl}$ & 124 & 62 & 31 & - \\
\hline $\mathrm{KCl}$ & 5 & 5 & 36 & - \\
\hline $\mathrm{CaCl}_{2}, 2 \mathrm{H}_{2} \mathrm{O}$ & 1.5 & 1.5 & 1.5 & - \\
\hline $\mathrm{NaH}_{2} \mathrm{PO}_{4}, \mathrm{H}_{2} \mathrm{O}$ & 3 & 3 & 3 & 3 \\
\hline $\mathrm{NaHCO}_{3}$ & 11.9 & 11.9 & 11.9 & 11.9 \\
\hline $\mathrm{MgSO}_{4}, 7 \mathrm{H}_{2} \mathrm{O}$ & 0.9 & 0.9 & 0.9 & 0.9 \\
\hline Glucose & 5.5 & 5.5 & 5.5 & 5.5 \\
\hline $\mathrm{NaNO}_{3}$ & - & - & - & 62 \\
\hline $\mathrm{KNO}_{3}$ & - & - & - & 5 \\
\hline $\mathrm{Ca}\left(\mathrm{NO}_{3}\right), 4 \mathrm{H}_{2} \mathrm{O}$ & - & - & - & 1.5 \\
\hline $\mathrm{pH}$ & 7.9 & 7.9 & 7.9 & 7.9 \\
\hline Osmolality (mOsm.kg-1) & $295.9 \pm 1.2$ & $176.3 \pm 4.5$ & $177.0 \pm 4.6$ & $175.1 \pm 3.6$ \\
\hline
\end{tabular}




\section{Cellular Physiology Cell Physiol Biochem 2021;55(S1):185-195 \\ \begin{tabular}{ll|l}
\hline DOI: 10.33594/000000440 & ( 2021 The Author(s). Published by
\end{tabular} \\ Published online: 20 October 2021 Cell Physiol Biochem Press GmbH\&Co. KG \\ Maxime: Coordination of Swelling-Activated Osmolytes Fluxes in Trout Red Blood Cells}

contents on the one hand, and $\mathrm{Cl}^{-}$content on the other, were determined by photometry (Instrumentation Laboratory flame photometer IL 243-05), and by colorimetry (Biolabo, kit 80005), respectively. Ion contents were expressed as $\mu$ mol per gram dry cell solids.

An attempt to dissect $\mathrm{Na}^{+}$pathways across cells membrane was performed by a pharmaceutical approach using amiloride (Sigma). It was dissolved in dimethyl sulfoxide (DMSO) and added to RBCs suspension ten minutes before and during the hyposmotic stress to yield a final concentration of $10^{-4} \mathrm{M}$. The lack of adverse effects of DMSO was checked beforehand. Osmolalities were measured with a vapor pressure osmometer (Wescor, model 5520).

\section{Calculations}

Considering that, in rainbow trout RBCs, no solute, other than $\mathrm{Na}^{+}, \mathrm{K}^{+}, \mathrm{Cl}^{-}$and taurine significantly contribute to RVD [11] and that the net loss of osmolytes is followed by an isosmotic loss of water, the taurine contribution as a function of time after swelling was calculated from the measured net changes of water, $\mathrm{K}^{+}, \mathrm{Cl}^{-}$and $\mathrm{Na}^{+}$contents. This approach is consistent with the method used by the above-mentioned authors who show that the calculated data correspond closely with the experimental ones. The hyposmotic salines containing on average $176 \mathrm{mmol}$ of osmolyte per litre of water, $5.68 \mathrm{ml}$ water is lost or gained for each mmol of osmolyte leaving or entering the cell. This calculation allowed also to estimate the respective participation of each inorganic osmolyte to RVD.

The intracellular $\mathrm{pH}\left(\mathrm{pH}_{\mathrm{i}}\right)$ was calculated from the chloride distribution across the RBCs membranes according to the Donnan equilibrium theory $\left(\mathrm{pH}_{\mathrm{i}}=\mathrm{pH}_{\mathrm{o}}+\log \left[\mathrm{Cl}^{-}\right]_{\mathrm{i}} /\left[\mathrm{Cl}^{-}\right]_{0}\right)$. The intracellular $\mathrm{pH}$ measurement using intracellular microelectrode or the freeze-thaw technique in fish RBCs produces results in agreement with this theory [22]. In the present study, $\mathrm{pH}_{\mathrm{o}}$ is the imposed $\mathrm{pH}$ of the experimental salines (Table 1) $\left[\mathrm{Cl}^{-}\right]_{\text {o }}$ was calculated from the chloride salts composition of these solutions $(132 \mathrm{mM}$ and $70 \mathrm{mM}$ for isosmotic and hyposmotic salines, respectively) $\left[\mathrm{Cl}^{-}\right]_{\mathrm{i}}$ expressed also in $\mathrm{mM}$, was calculated by dividing $\mathrm{Cl}^{-}$content by water content for each condition. pHi calculation is theoretically impossible for Hypo. III condition due to the lack of chlorides in the extracellular medium. Nevertheless, its trend has been estimated assuming a fictive concentration of $1 \mathrm{mM}$ for this anion.

\section{Statistical analyses}

Statistical analyses were conducted using Sigmastat 12.5 (Systat Software Inc.). All data were expressed as mean values \pm standard error of the means (S.E.M.). Differences were tested by a one-way ANOVA analysis. Whenever significant effects were detected, multiple comparisons were conducted using Holm-Sidak method. Differences were considered significant at $p<0.05$.

\section{Results}

In isosmotic saline (Fig. 1-3), the mean water content of trout RBCs was $2.03 \pm 0.03 \mathrm{~g}^{-\mathrm{g}^{-1}}$ d.c.s. and slightly decreased over the $90 \mathrm{~min}$. experimental period $(-11 \%) . \mathrm{K}^{+}$and $\mathrm{Cl}^{-}$contents ( 293 and $135 \mu$ mol. $\mathrm{g}^{-1}$ d.c.s., respectively) followed the same trend ( -7 and $-21 \%$, respectively). The RBCs suspension in the dilution of the physiological saline (Hypo. I condition) induced a rapid 43\% increase in water content, which was nearly cleared within 90 minutes (Fig. 1A). As shown in Fig. 1B-C, this effect was concurrent with a decrease in both $\mathrm{K}^{+}$and $\mathrm{Cl}^{-}$contents $\left(-21 \%\right.$ and $-44 \%$, respectively). A net $\mathrm{Na}^{+}$influx $(+22 \%)$ culminating after 30 minutes was also observed (Fig. 1D). According to Fig. 2A, when RBCs are in the hyposmotic saline with a high $\mathrm{K}^{+}$concentration (Hypo. II condition), the extent of the water content increase was slightly higher than the one observed in Hypo. I condition and the restoration was incomplete (66\% after 90 minutes). This condition did not bring any significant change in $\mathrm{K}^{+}, \mathrm{Cl}^{-}$and $\mathrm{Na}^{+}$ contents compared to isosmotic status (Fig. 2A-C). In a $\mathrm{Cl}^{-}$-free saline (Hypo. III condition), RBCs fully downregulated their water content after the same magnitude increase as in Hypo. I condition (Fig. 3A). The magnitude of the $\mathrm{K}^{+}$content decrease was quite similar with (- 21\% - Fig. 1B) or without $\mathrm{Cl}^{-}\left(-17 \%\right.$ - Fig. 3B). Fig. 3C shows that the $\mathrm{Cl}^{-}$content decreased drastically within the first five minutes due to an enlarged transmembrane gradient, to settle to a very low level (about $30 \mu \mathrm{mol}$. $\mathrm{g}^{-1}$ d.c.s). A significant increase in $\mathrm{Na}^{+}$content $(+46 \%$ at 30 min.) was also observed in this condition (Fig. 3D). 
Fig. 1. Effects of Hypo. I condition. Volumetric and ionic changes in trout RBCs further to exposure to isosmotic or hyposmotic salines. A: Water content as estimate of cell volume, B: Potassium content, C: Chloride content. D: Sodium content. d.c.s., dry cell solids. Filled symbols = isosmotic conditions ( $n=8)$, hollow symbols $=$ hyposmotic conditions $(\omega=176.3 \pm 4.5$ mOsm $\mathrm{kg}^{-1}, \mathrm{n}=10$ ). Values are means \pm S.E.M. Arrows indicate time of saline substitution. * indicates a significant difference $(p<0.05)$ with value obtained at the same time in isosmotic condition. + indicates a significant difference $(p<0.05)$ with value obtained before substitution of the initial solution for the hyposmotic saline.

Fig. 2. Effects of Hypo. II condition. Volumetric and ionic changes in trout RBCs further to exposure to isosmotic saline or hyposmotic saline with a high $\mathrm{K}^{+}$concentration. A: Water content as estimate of cell volume, B: Potassium content, C: Chloride content. D: Sodium content. d.c.s., dry cell solids. Filled symbols = isosmotic conditions $(\mathrm{n}=8)$, hollow symbols $=$ hypo-osmotic conditions $\left(\omega=177.0 \pm 4.6 \mathrm{mOsm} \mathrm{kg}{ }^{-1}\right.$, $\mathrm{n}=12$ ). Values are means \pm S.E.M. Arrows indicate time of saline substitution. * indi-
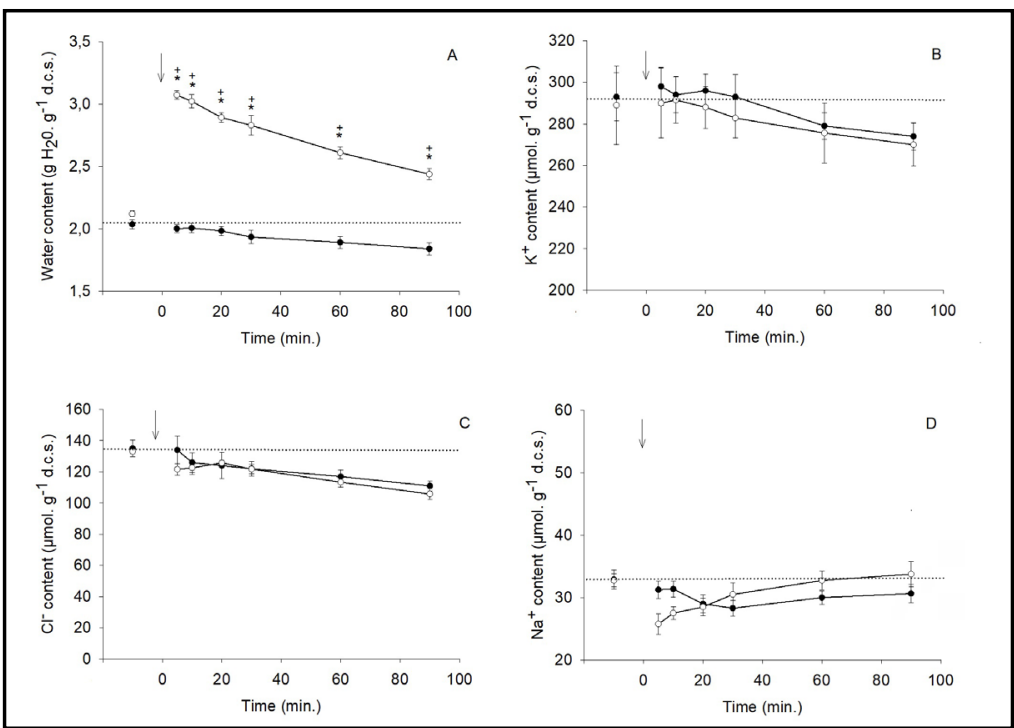
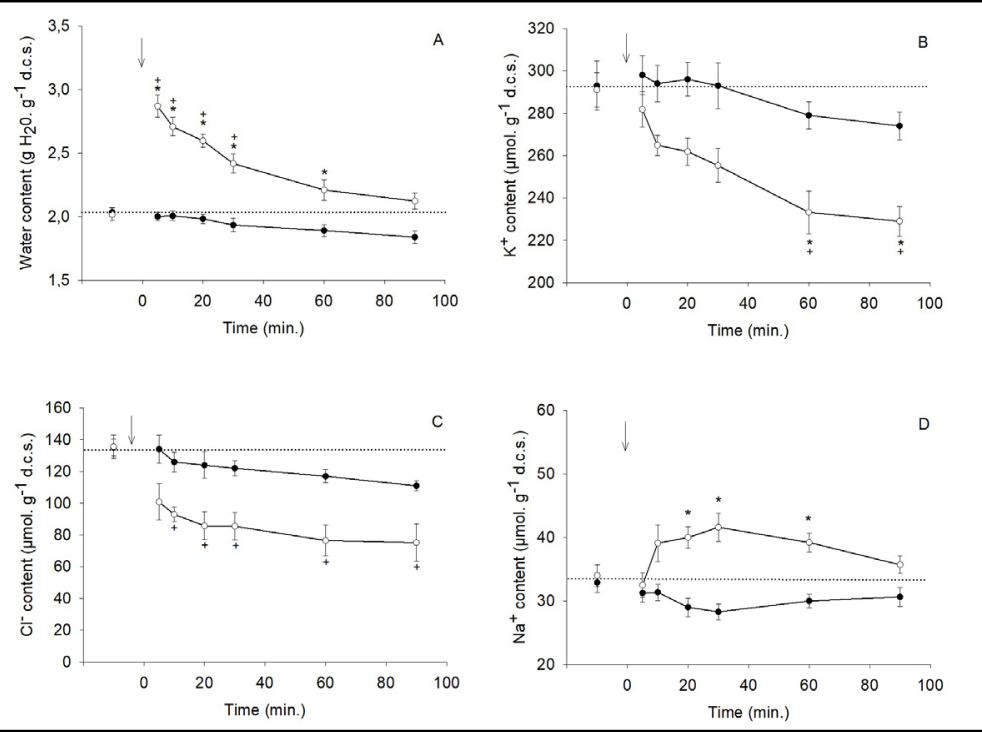
cates a significant difference $(p<0.05)$ with value obtained at the same time in isosmotic condition. + indicates a significant difference $(p<0.05)$ with value obtained before substitution of the initial solution for the hypo-osmotic saline.

The measured losses of water, $\mathrm{K}^{+}$and $\mathrm{Cl}^{-}$, and uptake of $\mathrm{Na}^{+}$allowed the calculation of taurine loss and its contribution to RVD in the three hyposmotic conditions as a function of time (Fig. 4). It was estimated on average to be $45 \%$ to the RVD process in Hypo. I condition. But, it was at first close to $100 \%$, then progressively settled down to about $69 \%$ in Hypo. II and Hypo. III conditions.

The $\mathrm{Na}^{+}$influx was non significantly inhibited by an extracellular $10^{-4} \mathrm{M}$ application of amiloride in all hyposmotic conditions (Fig. 5A-D). In the absence of hyposmotic shock, calculated pHi values (Fig. 6A-B) are in agreement with those reported for in vitro experiments realized in same conditions [22, 23]. Fig. 6A shows a similar stability of pHi for isosmotic and Hypo. I physiological status. But, Hypo. II condition induced a significant alkalosis $(\Delta \mathrm{pHi}=$ +0.1). Fig. 6B highlights a theoretical drastic alkalosis trend in Hypo. III condition. 
Fig. 3. Effects of Hypo. III condition. Volumetric and ionic changes in trout RBCs further to exposure to isosmotic saline or hyposmotic saline where $\mathrm{NO}_{3}^{-}$was used as a $\mathrm{Cl}^{-}$substitute. A: Water content as estimate of cell volume, B: Potassium content, C: Chloride content. D: Sodium content. d.c.s., dry cell solids. Filled symbols = isosmotic conditions ( $\mathrm{n}=8$ ), hollow symbols $=$ hypo-osmotic conditions $(\omega=175.1$ $\pm 3.6 \mathrm{mOsm} \mathrm{kg}{ }^{-1}, \mathrm{n}=12$ ). Values are means \pm S.E.M. Arrows indicate time of saline substitution. * indicates a
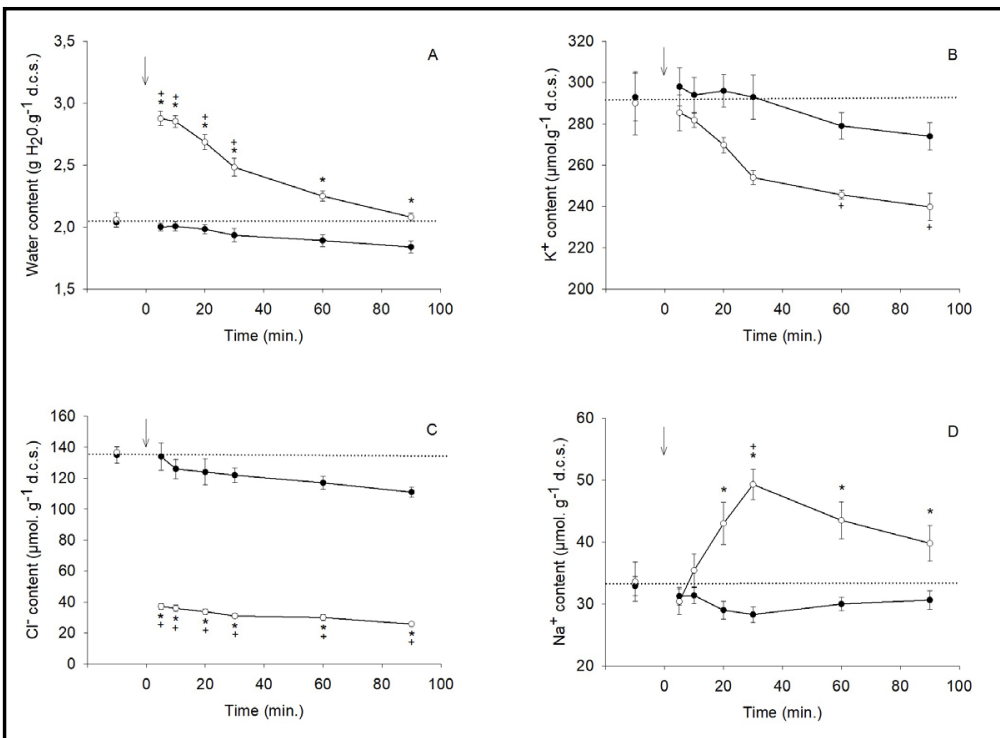

significant difference $(p<0.05)$ with value obtained at the same time in isosmotic condition. + indicates a significant difference $(p<0.05)$ with value obtained before substitution of the initial solution for the hypoosmotic saline.

Fig. 4. Contribution of taurine efflux to RVD in trout RBCs undergoing RVD after hyposmotic swelling $\left(\omega \approx 176 \mathrm{mOsm} \cdot \mathrm{kg}^{-1}\right)$. Mean values \pm S.E.M. were calculated from water and ion contents assuming that no solute, other than $\mathrm{K}^{+}, \mathrm{Cl}^{-}, \mathrm{Na}^{+}$and taurine contribute significantly to RVD [11]. Hypo. I: green symbols; Hypo. II (High-K ${ }^{+}$): blue symbols; Hypo. III ( $\mathrm{Cl}-$-free): orange symbols. * indicates a significant difference $(p<0.05)$ with value obtained at the same time in hyposmotic conditions.

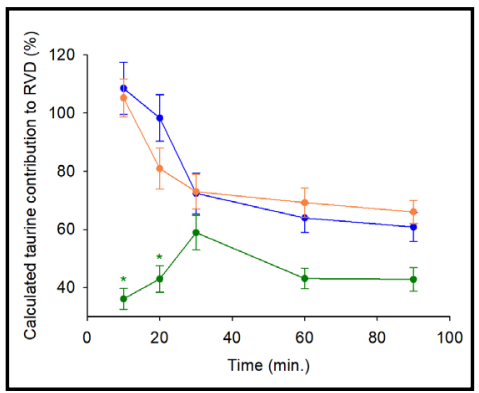

Fig. 5. Evidence of an amiloride-sensitive $\mathrm{Na}^{+}$pathway in trout RBCs undergoing RVD after hyposmotic swelling $\left(\omega \approx 176\right.$ mOsm. $\left.\mathrm{kg}^{-1}\right)$. A: isosmotic saline, $\mathrm{B}$ : hyposmotic saline (Hypo. I), C: High- $\mathrm{K}^{+}$hyposmotic saline (Hypo. II), D: $\mathrm{Cl}^{-}$-free hyposmotic saline (Hypo. III). d.c.s., dry cell solids. circle $=$ without amiloride, triangle $=$ with $10^{-4} \mathrm{M}$ amiloride. Values are means \pm S.E.M. Arrows indicate time of saline substitution. No significant difference was detected.

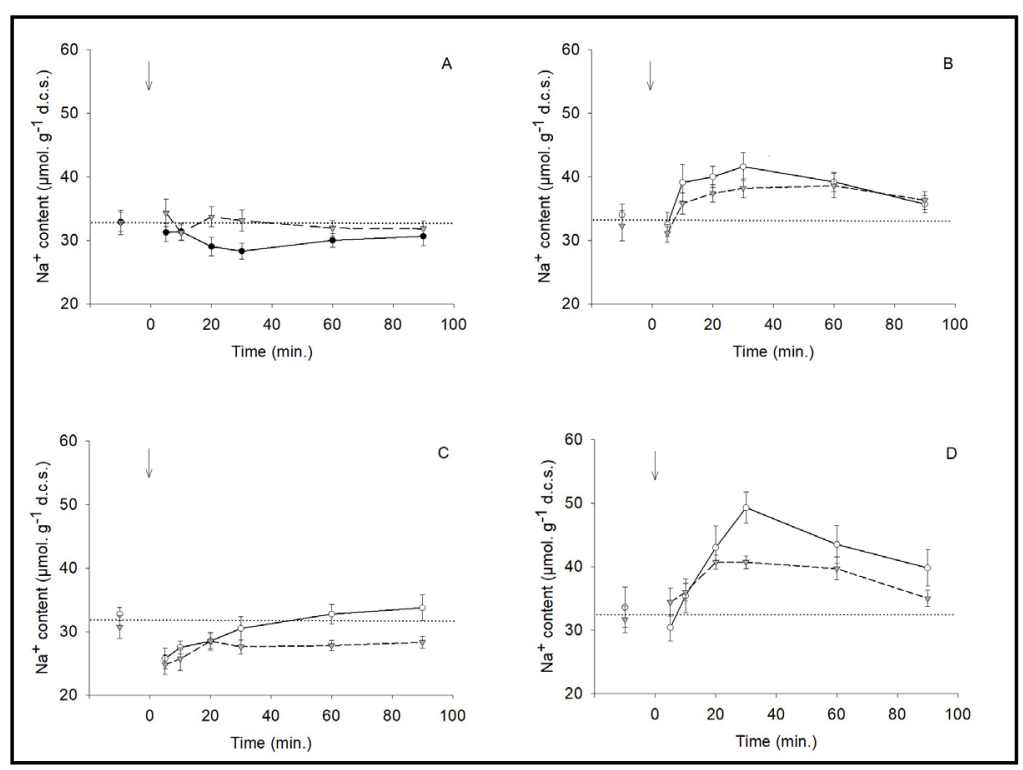




\section{Cellular Physiology Cell Physiol Biochem 2021;55(S1):185-195 \\ \begin{tabular}{ll|l} 
and Biochemistry & $\begin{array}{l}\text { DOl: 10.33594/000000440 } \\
\text { Published online: 20 October } 2021\end{array}$ & $\begin{array}{l}\text { O 2021 The Author(s). Published by } \\
\text { Cell Physiol Biochem Press GmbH\&Co. KG }\end{array}$ \\
\cline { 2 - 3 }
\end{tabular}

Fig. 6. Theoretical evolution of cytosolic $\mathrm{pH}$ in trout RBCs undergoing RVD after hyposmotic swelling $(\omega \approx 176$ mOsm. $\left.\mathrm{kg}^{-1}\right)$. A: Under isosmotic (red symbols) and Hyposmotic conditions (I: green symbols and II: High- $\mathrm{K}^{+}$- blue symbols), pHi was calculated from the chloride distribu-
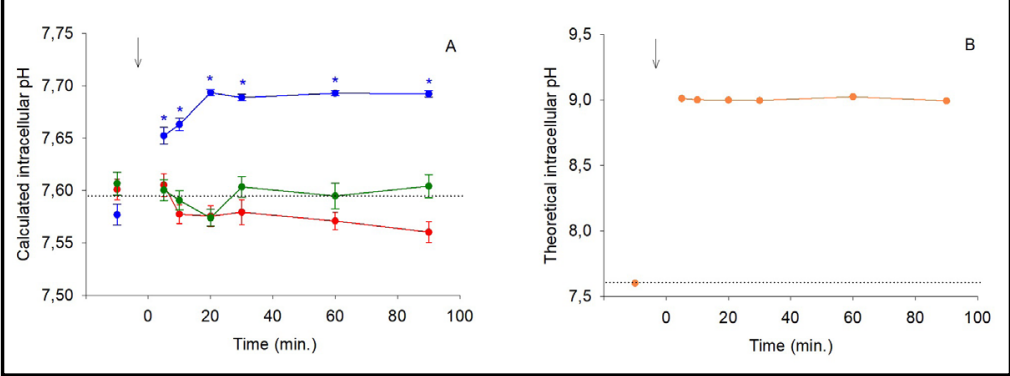
tion across the red cell mem-

brane according to the Donnan equilibrium. Values are means \pm S.E.M. * indicates a significant difference $(p<0.05)$ with value obtained before substitution of the initial solution for the hypo-osmotic saline. B: To highlight a tendency, the same calculation was made in Hypo. III condition ( $\mathrm{Cl}^{-}$-free) assuming an extracellular chloride concentration of $1 \mathrm{mM}$ (instead of $0 \mathrm{mM}$ ).

Fig. 7. Snapshot view, at time $30 \mathrm{~min}$., of the flexible involvement of all the osmolytes in the RVD process as a function of the experimental hypoosmotic conditions $\left(\omega \approx 176 \mathrm{mOsm} \cdot \mathrm{kg}^{-1}\right)$. Values are means \pm S.E.M. For each osmolyte, different letters above or below bars indicate significant differences between hypoosmotic conditions $(p<0.05)$.

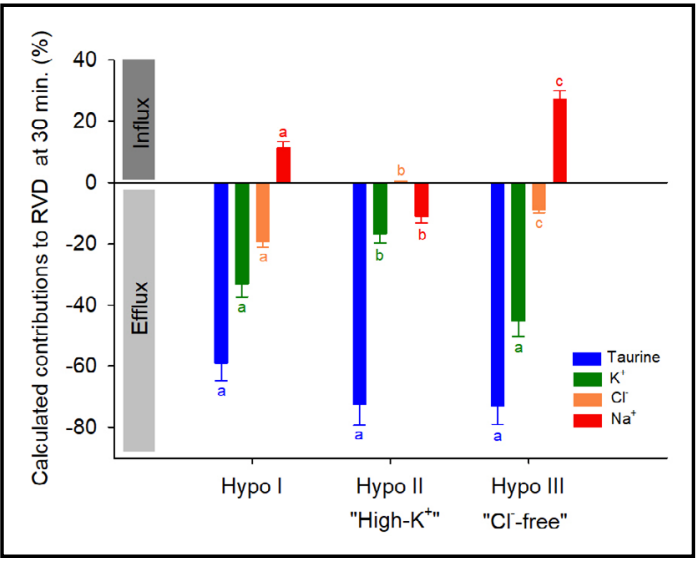

Fig. 7 is an overview of the ionic and organic osmolytes calculated relative contributions to RVD after a 30 minutes RBCs exposure to hyposmotic salines. This delay corresponds to the maximal $\mathrm{Na}^{+}$content increase. It shows the significant role played by taurine and highlights the modulations of the osmolytes fluxes resulting from the different experimental conditions.

\section{Discussion}

Water contents changes are interpreted as variations of RBCs' volume. Under isosmotic conditions, RBCs slightly shrunk concomitantly with a small leak of $\mathrm{K}^{+}$(despite the $\left(\mathrm{Na}^{+}, \mathrm{K}^{+}\right.$) ATPase pump activity) and $\mathrm{Cl}^{-}$. This is in accordance with the very low transmembrane diffusion of inorganic substances reported under similar conditions [18]. A low taurine flux in isosmotic trout RBCs may also cause this progressive cell dehydration [13].

In line with previous investigations in fish cells, hyposmotic swelling of trout RBCs led to the regulatory decrease of their volume. The latter could be explained by a net loss of both $\mathrm{K}^{+}$and $\mathrm{Cl}^{-}$dragging water out. The $\mathrm{Na}^{+}$uptake, down its electrochemical gradient and despite the $\left(\mathrm{Na}^{+}, \mathrm{K}^{+}\right)$ATPase pump activity, may have delayed the process by transiently promoting water uptake. It is common knowledge that $\mathrm{K}^{+}$and $\mathrm{Cl}^{-}$use two different exit pathways: a KCl cotransport and separate selective channels. These components of RVD process are activated by the dilution of intracellular electrolytes (i.e. by the decrease in ionic strength) [23] and/ or by the mechanical deformation of the membrane [18]. The present findings confirm their involvement in RVD. As a matter of fact, the simultaneous total inhibition of these 


\section{Cellular Physiology Cell Physiol Biochem 2021;55(S1):185-195 \\ \begin{tabular}{ll|l} 
and Biochemistry & $\begin{array}{l}\text { DOl: 10.33594/000000440 } \\
\text { Published online: 20 October } 2021\end{array}$ & $\begin{array}{l}\text { O 2021 The Author(s). Published by } \\
\text { Cell Physiol Biochem Press GmbH\&Co. KG }\end{array}$ \\
\cline { 2 - 3 }
\end{tabular} \\ Maxime: Coordination of Swelling-Activated Osmolytes Fluxes in Trout Red Blood Cells}

ions effluxes (expected for $\mathrm{K}^{+}$) under the Hypo. II condition, would suggest a full coupling and the exclusive participation of a $\mathrm{KCl}$ cotransporter. This is the case after an isosmotic swelling [23]. However, Hypo. III condition where $\mathrm{NO}_{3}^{-}$was used as a $\mathrm{Cl}^{-}$substitute, bring the demonstration that $\mathrm{K}^{+}$and $\mathrm{Cl}^{-}$effluxes can also be performed independently. Indeed, the full cell volume restoration was based on a low effect of chlorides (about 8\% contribution, after the instant enforced leak) and on a $\mathrm{K}^{+}$efflux equivalent to the one observed after a physiologic swelling (Hypo. I condition). Thus, distinct $\mathrm{Cl}^{-}$and $\mathrm{K}^{+}$pathways also co-exist in trout RBCs membranes. Direct evidence has been provided, using patch clamp techniques, for the reversible activation by cell swelling and/or membrane deformation of two distinct channels: the net $\mathrm{Cl}^{-}$and $\mathrm{Cl}^{-}$-independent $\mathrm{K}^{+}$effluxes are mediated by outwardly rectifying $\mathrm{Cl}^{-}$channels (ORCC) and nonselective cationic channels (NSC), respectively [18]. The present results confirm the concomitant involvement of channels and cotransport for $\mathrm{K}^{+}$and $\mathrm{Cl}^{-}$ effluxes, but do not allow an estimation of their relative contributions to the RVD process. However, the release of $\mathrm{K}^{+}$and $\mathrm{Cl}^{-}$would occur essentially through separate pathways after a hyposmotic swelling $[18,23]$.

The Hypo. II condition highlights the contribution of osmolytes other than $\mathrm{K}^{+}$and $\mathrm{Cl}^{-}$to RVD process. It probably acts of taurine which, according to the literature in fish, contributes between $30 \%$ and $50 \%$ to the RVD process. The present experimentation under Hypo. I physiologic condition leads to a similar estimation (between about $40 \%$ and $60 \%$, as a function of time). However, when cells were hyposmotically swollen in high $\mathrm{K}^{+}$(Hypo. II) or $\mathrm{Cl}^{-}$-free (Hypo. III) salines, the fraction of the osmolyte loss accounted for by taurine significantly increased, being at first exclusive as already reported [23]. Then, it progressively settled down to a high level which could be considered as an offset of the forced declined participations of $\mathrm{K}^{+}$and $\mathrm{Cl}^{-}$to RVD. However, taurine loss appeared insufficient to a full RVD in Hypo. II condition.

Considering the transmembrane exchanges of electrical charges under Hypo. I condition at $90 \mathrm{~min}$, the net loss of $60.3 \pm 4.7 \mu$ equiv. $\mathrm{g}^{-1}$ d.c.s. positive charges $\left(\mathrm{K}^{+}\right.$minus $\mathrm{Na}^{+}$) was electrically balanced by $62.1 \pm 4.9 \mu$ equiv. ${ }^{-1}$ d.c.s. $\mathrm{Cl}^{-}$loss. The balance of charges can also be regarded as nil in the Hypo. II condition characterized by an absence of significant movements of ionic osmolytes. These results confirm that taurine is released as a zwitterion [11]. Besides, the electroneutral form of this solute is the predominant one at physiological $\mathrm{pH}$ as indicated by its pKa values of 1.05 and 9.06 [24]. However, the prior near annulment of $\mathrm{Cl}^{-}$content in Hypo. III condition obliged the taurine to be transported as an anion. Thus, taurine loss also would aid to maintain the transmembrane potential during RVD process.

In vertebrates, the hyposmotically-induced efflux of taurine is mediated by pathways characterized by their broad specificity whose nature is not clear. It may be in fact the result of more than one system [25]. In fish RBCs, quite a few works evidenced that swellinginduced taurine loss occurs via the band 3 protein. This membrane protein may act both as an anion exchanger (as in mammals) and, after a conformational change, as a channel with a wide variety of charged and uncharged solutes [26].

To our knowledge, a $\mathrm{Na}^{+}$uptake during RVD, despite the $\left(\mathrm{Na}^{+}, \mathrm{K}^{+}\right)$ATPase pump activity, has never been shown elsewhere than in rainbow trout RBCs. In the present experiment, it is noticeable in Hypo. I and Hypo. III conditions and reaches its highest level after $30 \mathrm{~min}$. The transitory decrease in $\mathrm{Na}^{+}$content observed in Hypo. II condition would be in relation to the decreased transmembrane diffusive gradient for this cation. These findings prompt the question of the way(s) and of the reason of this $\mathrm{Na}^{+}$influx in RVD. It is assumed that it is a result of taurine transports. Indeed, the taurine release likely stimulates an offsetting taurine influx. The latter is achieved primarily by a $\mathrm{Na}^{+}$-dependent process, with $\mathrm{Na}^{+}$ being co-transported into the cell [27]. For example, $\mathrm{Na}^{+}$-dependency is a characteristic of a large fraction of the influx of taurine in flounder erythrocytes [16]. In agreement with this hypothesis, the taurine efflux and the $\mathrm{Na}^{+}$uptake rises, calculated at $30 \mathrm{~min}$, are equal $(+13.2 \pm 1.0 \%$ and $+14.9 \pm 1.5 \%$, respectively) between Hypo. I and Hypo. III conditions (both showing a full completion of RVD). An enlarged contribution of taurine has also been 


\section{Cellular Physiology Cell Physiol Biochem 2021;55(S1):185-195 \\ \begin{tabular}{ll|l} 
DOl: 10.33594/000000440 & O 2021 The Author(s). Published by \\
Cell Physiol Biochem Press GmbH\&Co. KG
\end{tabular} \\ Maxime: Coordination of Swelling-Activated Osmolytes Fluxes in Trout Red Blood Cells}

demonstrated in Hypo. II condition. However, it cannot be correlated to a proportional $\mathrm{Na}^{+}$uptake. Indeed, as a result of the imposed decreased $\mathrm{K}^{+}$transmembrane gradient, this condition promotes an inhibition of the $\left(\mathrm{Na}^{+}, \mathrm{K}^{+}\right)$ATPase pump activity which consequently, cannot supply indirect energy for the $\mathrm{Na}^{+}$/taurine cotransport. This is likely also the reason of the partial RVD which follows a depletion of the taurine intracellular stock.

Contrary to the data obtained in the same species [12], the $\mathrm{Na}^{+}$influx was partly inhibited by amiloride in all hyposmotic conditions. In mammals, amiloride is known to affect $\mathrm{Na}^{+}$ transport systems, among which $\mathrm{Na}^{+}$specific channels [28] and the $\mathrm{Na}^{+} / \mathrm{H}^{+}$antiporter [29] figure prominently. Moreover, $\mathrm{Na}^{+}$- dependent taurine cotransport has been referred to as being amiloride-insensitive [30-32]. Assuming these observations are transposable to fish, this cotransport would be the main but not the only pathway for $\mathrm{Na}^{+}$uptake. In trout $\mathrm{RBCs}$, the $\mathrm{Na}^{+} / \mathrm{H}^{+}$antiporter is distinct in that it does not regulate pHi [22, 33]. However, its hypothetical activation explaining $\mathrm{Na}^{+}$influx could induce an increase in pHi. But, Hypo. I condition is characterized by the relative steadiness of pHi due to the stability of intracellular $\mathrm{Cl}^{-}$concentration $\left(\left[\mathrm{Cl}^{-}\right]_{\mathrm{i}}=34.6 \pm 0.4 \mathrm{mM}\right)$ over the full time course of RVD. Actually, the taurine plays a pivotal role in maintaining constant $\mathrm{pHi}$, as long as its loss is stoichiometrically related to cation movements and $\mathrm{Cl}^{-}$loss [11]. Thus, the taurine loss contributes also to the acid-base homeostasis of the cell. The lack of alkalosis leads to exclude the $\mathrm{Na}^{+} / \mathrm{H}^{+}$exchanger participation to the $\mathrm{Na}^{+}$uptake in Hypo. I condition. Assuming it is also the case in Hypo. II and III conditions, the cause of the foreseen (by calculation) cellular alkalosis must be sourced elsewhere. Under Hypo. II condition, the $\mathrm{K}^{+}$and $\mathrm{Na}^{+}$diffusive gradients are divided by 7 and 2, respectively, if compared with Hypo. I condition. The $\mathrm{Cl}^{-}$efflux associated to $\mathrm{K}^{+}$is therefore $3.5 \mathrm{x}$ more reduced than its influx when linked to $\mathrm{Na}^{+}$, explaining the net increase of this anion concentration $\left(\left[\mathrm{Cl}^{-}\right]_{\mathrm{i}}=42.3 \pm 3.2 \mathrm{mM}\right)$. Thus, the ratio $\left[\mathrm{Cl}^{-}\right]_{\mathrm{i}} /\left[\mathrm{Cl}^{-}\right]_{\mathrm{o}}$ is higher in Hypo. II (about 0.58), than in isosmotic and Hypo. I conditions (about 0.48). That leads to an increase in $\mathrm{pHi}$ in the high $\mathrm{K}^{+}$medium. The drastic alkalosis forecasted in Hypo. III condition is due to the annulment of the saline chloride concentration. In both cases, the alkalosis is not an effect of the RVD process. Moreover, NSC channels not only mediate the $\mathrm{K}^{+}$efflux but also a $\mathrm{Na}^{+}$entry [18]. These channels are known to be amiloride-sensitive in mammal lung cells [34]. It is assumed that it is the same in trout RBCs. Thus, a minor part of the $\mathrm{Na}^{+}$influx observed during RVD would be due to NSC activity.

\section{Conclusion}

Hyposmotic swelling of trout RBCs activates different permeability pathways with modular respective importance depending on experimental conditions. By artificially decreasing the contributions of $\mathrm{K}^{+}$and $\mathrm{Cl}^{-}$effluxes, this work evidences an accurate coordination between these pathways. Thus, the taurine appears as a compensatory variable not only for the cell volume regulation but also for the membrane potential care and the acid base homeostasis. The taurine loss is related to a proportional $\mathrm{Na}^{+}$entry which contrary to appearances, participates fully to the RVD achievement. This coordination obviously results from the operation of a complex signalling pathways network which remains to be explored.

\section{Acknowledgements}

The author thanks A. Mézergues for her technical assistance and Pr. O. Sire for his careful and critical reading of the manuscript.

Statement of Ethics

Animal procedures were in accordance with the French (articles R214-87 à R214-137 du code rural) and EU (Directive 2010/63/EU) guidelines for animal research. 


\section{Cellular Physiology Cell Physiol Biochem 2021;55(S1):185-195 \begin{tabular}{l|l|l} 
DOI: 10.33594/000000440 2021 The Author(s). Published by & C
\end{tabular} and Biochemistry Published online: 20 October 2021 Cell Physiol Biochem Press GmbH\&Co. KG \\ Maxime: Coordination of Swelling-Activated Osmolytes Fluxes in Trout Red Blood Cells}

\section{Disclosure Statement}

The author declares that no conflict of interests exists.

\section{References}

1 Chara O, Espelt MV, Krumschabel G, Schwarzbaum PJ: Regulatory volume decrease and P receptor signalling in fish cells: mechanisms, physiology, and modelling approaches. J Exp Zool 2011;315:175-202.

2 Baroin A, Garcia-Romeu F, Lamarre T, Motais R: A transient sodium-hydrogen exchange system induced by catecholamines in erythrocytes of rainbow trout (Salmo gairdneri). J Physiol 1984;356:21-31.

3 Hoffmann EK, Lambert IH, Pedersen SF: Physiology of cell volume regulation in vertebrates. Physiol Rev 2009;89:193-277.

$4 \quad$ Kirk K: Swelling-activated Organic Osmolyte Channels. J Membr Biol 1997;158:1-16.

5 Motais R, Guizouarn H, Borgèse F: The swelling-sensitive osmotic channel; in Bernhardt I, Ellory JC (eds): Red cell membrane transport in health and disease. Berlin/Heidelberg/New York, Springer-Verlag, 2003, pp 153-171.

6 Brill SR, Musch MW, Goldstein L: Taurine efflux, band 3 and erythrocyte volume of hagfish (Myxina glutinosa) and lamprey (Petromyzon marinus). J Exp Zool 1992;264:19-25.

7 Davis-Amaral EM, Musch MW, Goldstein L: Chloride and taurine effluxes occur by different pathways in skate erythrocytes. Am J Physiol 1996;271:R1544-R1549.

8 Fincham DA, Wolowyk MW, Young JD: Volume sensitive taurine transport in fish erythrocytes. J Membr Biol 1987;96:45-56.

9 Lewis RA, Bursell JDH, Kirk K: Anion selectivity of the swelling-activated osmolyte channel in eel erythrocytes. J Membr Biol 1996;149:103-111.

10 Jensen F: Regulatory volume decrease in carp red blood cells: mechanisms and oxygen-dependency of volume-activated potassium and amino acid transport. J Exp Biol 1995;198:155-165.

11 Guizouarn H, Motais R, Garcia-Romeu F, Borgese F: Cell volume regulation: the role of taurine loss in maintaining membrane potential and cell pH. J Physiol 2000;523:147-154.

12 Garcia-Romeu F, Cossins AR, Motais R: Cell volume regulation by trout erythrocytes: characteristics of the transport systems activated by hypotonic swelling. J Physiol 1991;440:547-567.

13 Kiessling K, Ellory JC, Cossins AR: The relationship between hypotonically-induced taurine and K fluxes in trout red blood cells. Pflügers Arch 2000;440:467-475.

14 Wormser C, Mason LZ, Helm EM, Light DB: Regulatory volume response following hypotonic stress in Atlantic salmon erythrocytes. Fish Physiol Biochem 2011;37:745-759.

15 Nonnotte G, Truchot JP: Cell volume regulation by erythrocytes of the euryhaline fish, Platichthys flesus, after hyposmotic stress in bicarbonate/carbon-dioxide-buffered medium. Cell Physiol Biochem 1992;2:336-348.

16 Thoroed SM, Fugelli $\mathrm{K}$ : The $\mathrm{Na}^{+}$-independent taurine influx in flounder erythrocytes and its association with the volume regulatory taurine efflux. J Exp Biol 1994;186:245-268.

17 Godart H, Ellory JC, Motais R: Regulatory volume response of erythrocytes exposed to a gradual and slow decrease in medium osmolality. Pflugers Arch 1999;437:776-779.

18 Egée S, Lapaix F, Cossins AR, Thomas SL: The role of anion and cation channels in volume regulatory responses in trout red blood cells. Bioelectrochemistry 2000;52:133-149.

19 Wehner F, Olsen H, Tinel H, Kinne-Saffran E, Kinne RKH: Cell volume regulation: osmolytes, osmolyte transport, and signal transduction. Rev Physiol Biochem Pharmacol 2003;148:1-80.

20 Krumschnabel G, Gstir R, Manzl C, Prem C, Pafundo D, Schwarzbaum PJ: Metabolic and ionic responses of trout hepatocytes to anisosmotic exposure. J Exp Biol 2003;206:1799-1808.

21 Wolf K: Physiological salines for fresh-water teleosts. Prog Fish Cult 1963;25:135-140.

22 Thomas S, Egée S: Fish red blood cells: characteristics and physiological role of the membrane ion transporters. Comp Biochem Physiol A 1998;119:79-86.

23 Guizouarn H, Motais R: Swelling activation of transport pathways in erythrocytes: effects of $\mathrm{Cl}^{-}$, ionic strength, and volume changes. Am J Physiol 1999;276:C210-C220. 


\section{Cellular Physiology Cell Physiol Biochem 2021:55(S1):185-195 \\ \begin{tabular}{ll|l|l|l}
\hline DOl: 10.33594/000000440 & 2021 The Author(s). Published by
\end{tabular} \\ and Biochemistry Published online: 20 October 2021 Cell Physiol Biochem Press GmbH\&Co. KG \\ Maxime: Coordination of Swelling-Activated Osmolytes Fluxes in Trout Red Blood Cells}

24 National Center for Biotechnology Information (2021): PubChem Annotation Record for Taurine, Source: Hazardous Substances Data Bank (HSDB) [cited 2020, August 12]. URL: https://pubchem.ncbi.nlm.nih.gov/ source/hsdb/8167.

25 Shennan DB: Swelling-induced taurine Transport: relationship with chloride channels, anion-exchangers and other swelling-activated transport pathways. Cell Physiol Biochem 2008;21:15-28.

26 Guizouarn H, Gabillat N, Motais R, Borgèse F: Multiple transport functions of a red blood cell anion exchanger, tAE1: its role in cell volume regulation. J Physiol 2001;535:497-506.

27 Huxtable RJ: Physiological actions of taurine. Physiol Rev 1992;72:101-163.

28 Alvarez de la Rosa D, Canessa CM, Fyfe GK, Zhang P: Structure and regulation of amiloride sensitive sodium channels. Annu Rev Physiol 2000;62:573-594.

29 Harris C, Fliegel: Amiloride and the $\mathrm{Na}^{+} / \mathrm{H}^{+}$exchanger protein: mechanism and significance of the $\mathrm{Na}^{+} / \mathrm{H}^{+}$ exchanger. Int J Mol Med 1999;3:315-321.

30 Chesney RW, Gusowski N, Dabbagh S, Theissen M, Padilla M, Diehl A: Factors affecting the transport of $\beta$-amino acids in rat renal brush-border membrane vesicles. The role of external chloride. Biochim Biophys Acta 1985;812:702-712.

31 Zelikovic I, Chesney RW: Ionic requirements for amino acid transport. Am J Kidney Dis 1989;14:313-316.

32 Jones DP, Miller LA, Dowling C, Chesney RW: Regulation of taurine transporter activity in LLC-PK1 cells: Role of protein synthesis and protein kinase C activation. J Am Soc Nephrol 1991;2:1021-1029.

33 Malapert M, Guizouarn H, Fievet B, Jahns R, Garcia-Romeu F, Motais R, Borgèse F: Regulation of $\mathrm{Na}^{+} / \mathrm{H}^{+}$ antiporter in trout red blood cells. J Exp Biol 1997;200:353-360.

34 Chen XJ, Eaton DC, Jain L: Alveolar epithelial ion and fluid transport $\beta$-adrenergic regulation of amiloridesensitive lung sodium channels. Am J Physiol Lung Cell Mol Physiol 2002;282:L609-L620. 